\title{
Ionic Liquids Mediated Ionothermal Process for the One-Step Synthesis of High Surface Area Alumina Supported Noble Metals
}

\author{
Magali Bonne ${ }^{1}$, Pierrick Gaudin ${ }^{1}$, Yanlong Gu ${ }^{3}$, François Jérôme², \\ Yannick Pouilloux ${ }^{2}$, Daniel Duprez ${ }^{2}$, Sébastien Royer ${ }^{2}$ \\ ${ }^{1}$ Université de Haute Alsace (UHA), CNRS, Equipe Matériaux à Porosité Contrôlée (MPC), Institut de Science \\ des Matériaux de Mulhouse (IS2M), Mulhouse, France \\ ${ }^{2}$ Université de Poitiers, Institut de Chimie des Milieux et Matériaux de Poitiers (IC2MP), Poitiers, France \\ ${ }^{3}$ Institute of Physical Chemistry and Industrial Catalysis, Department of Chemistry and Chemical Engineering, University of Science \\ and Technology, Wuhan, China \\ Email: magali.bonne@uha.fr
}

Received March 25, 2013; revised April 27, 2013; accepted May 23, 2013

Copyright (C) 2013 Magali Bonne et al. This is an open access article distributed under the Creative Commons Attribution License, which permits unrestricted use, distribution, and reproduction in any medium, provided the original work is properly cited.

\begin{abstract}
Aluminas supported noble metal nanoparticles have been synthesized by a new ionothermal process. The method used is easy to implement and allows obtaining catalysts in one step with high specific surface area. In addition, the metallic phase in the composites is highly dispersed and exhibits homogeneous size.
\end{abstract}

Keywords: Mesostructuration; Alumina; Noble Metals; Ionothermal Process; EISA

\section{Introduction}

Since the discovery of the M41S family by Mobil, the interest in mesostructured materials becomes more and more important due to the possibility of controlling the pore structure of solids [1,2]. Indeed their tuneable properties allow emerging applications in different fields, amongst physics, medicine, catalysis, etc. Among all the materials studied, the synthesis of $\mathrm{Al}_{2} \mathrm{O}_{3}$ with high specific surface area still represents a major challenge for chemical industries because of its extensive use as adsorbents and catalysts supports for numerous applications such as catalytic cracking, hydrocarbons reforming, environmental reactions, etc. Among the known structures of alumina, the $\gamma-\mathrm{Al}_{2} \mathrm{O}_{3}$ transition form is the most used as catalyst support. Indeed, the morphology of the boehmite (hydrate precursor) confers to the $\gamma$-form adequate textural and surface chemical properties. Consequently, the synthesis of mesoporous aluminas is currently extensively studied in the literature [3-7]. In most cases, these syntheses are generally made by a solvothermal process, with processes very close to the classical ones with structuring agent added to the synthesis media [8].

To overcome the use of a hydrothermal synthesis, with the well-known limitation associated to the pressure increase with temperature, it is possible to use nonaqueous solvents [9]. In this line, Room Temperature Ionic Liquids (RTILs) are considered as organic solvents with high polarity and preorganized solvent structures [10]. RTILs received more and more attention since the last decade. Indeed, they can be considered as liquids at room temperature, or temperature $<100^{\circ} \mathrm{C}$, meaning the presence of ions only [11]. Moreover their physical and chemical properties are very interesting in the viewpoint of inorganic material synthesis. They exhibit low melting point $\left(<100^{\circ} \mathrm{C}\right)$, negligible vapour pressure, thermal stability, high polarity and high ionic conductivity [12-14]. Facile route syntheses are described in literature using RTILs as solvents that catalyse some processes [15-23] but recent developments using RTILs as templating agents have also been described [25-33]. Indeed, one of the advantages of RTILs is that they can form extended hydrogen bond systems and are therefore highly structured which is adequate for the condensation of an inorganic matter to obtain structured pore systems [34].

In this work, we report a method allowing the direct (one-pot synthesis) functionalization of aluminas by noble metals using the Evaporation Induced Self Assembly (EISA) process. Noble metals are selected for their extensive use in heterogeneous catalysis, in environment and energy conversion applications. 


\section{Experimental Section}

For the syntheses described here, the RTIL used is $\mathrm{C}_{10}$ mimCl. Pt, $\mathrm{Pd}$ and $\mathrm{Rh}$ functionalization of the aluminas will be done in one-pot synthesis.

In a typical synthesis 1-decyl, 3-methylimidazole chloride $\left(\mathrm{C}_{10} \mathrm{mimCl}\right)$ is obtained by mixing $53.9 \mathrm{~g}(0.65$ mol) of 1-methylimidazole (99\%) and $117.2 \mathrm{~g}(0.65 \mathrm{~mol})$ of decyl chloride $(98 \%)$ is stirred during $72 \mathrm{~h}$ at $80^{\circ} \mathrm{C}$ in a $500 \mathrm{~mL}$ round bottom flask equipped with a condenser. The yellow oil obtained is washed three times with ethyl acetate then the solvent is evaporated at $60^{\circ} \mathrm{C}$ under vacuum during $24 \mathrm{~h}$.

$\gamma-\mathrm{Al}_{2} \mathrm{O}_{3}$ is synthesized according to an EISA procedure, as successfully used by Yuan et al. [4] for the synthesis of hexagonal-type pore structure aluminas. $\mathrm{C}_{10} \mathrm{mimCl}$, as template and co-solvent, is dissolved in anhydrous ethanol (solution $\mathrm{pH}$ closed to 7). $\mathrm{HNO}_{3} 65 \mathrm{wt} \%$ is added to the solution in order to acidify the media $(\mathrm{pH} \sim 1.4)$. Then a quantity of Al-sec-butoxide is added, the solution is stirred at room temperature for $5 \mathrm{~h}$. The gel composition is: $1 \mathrm{Al}: 0.65 \mathrm{C}_{10}$ mimCl: $3.8 \mathrm{H}_{2} \mathrm{O}: 35 \mathrm{EtOH}: 2.1$ $\mathrm{HNO}_{3}$. The solvent is evaporated at $60^{\circ} \mathrm{C}$ in an oven until the solid is completely dry ( $\sim 10$ days). The solid obtained is calcined for $4 \mathrm{~h}$ at $550^{\circ} \mathrm{C}$ in a muffle furnace, which is enough to ensure the complete removal of any carbonaceous matter for the solid (temperature increase ramp: $\left.1^{\circ} \mathrm{C} \cdot \mathrm{min}^{-1}\right)$. The obtained alumina is denoted: Al-EISA.

The synthesis of the functionalized alumina is performed as described for the alumina. Before adding the aluminium precursor, a known quantity of noble metal precursor $\left(\mathrm{H}_{2} \mathrm{PtCl}_{6}, \mathrm{Pd}\left(\mathrm{NO}_{3}\right)_{2}\right.$ or $\left.\mathrm{RhCl}_{3}\right)$ diluted in a solvent, is added in order to obtain a $1 \mathrm{wt} \%$ loading of metal, dispersed in the $\mathrm{Al}_{2} \mathrm{O}_{3}$ matrix. After calcination, the samples are reduced at $500^{\circ} \mathrm{C}$ under $\mathrm{H}_{2}$ flow for obtaining the supported metallic phase. The nomenclature used for the samples is as follows:

NM-Al-EISA

where $N M$ designs the noble metal: $\mathrm{Pt}, \mathrm{Pd}$ or $\mathrm{Rh}$.

RTIL was analyzed by ${ }^{1} \mathrm{H}$ and ${ }^{13} \mathrm{C}$ NMR spectroscopy. The spectra were recorded on a BRUKER ADVANCE DPX 300 and 400.

Powder wide angle XRD patterns were obtained on a BRUKER AXS D5005 X-ray diffractometer, using a $\mathrm{CuK} \alpha$ radiation $(\lambda=1.54184 \AA)$ as $\mathrm{X}$-ray source and equipped with a SolX detector. Signal was recorded for $2 \theta$ comprised between $10^{\circ}$ and $80^{\circ}$ with a step of $0.05^{\circ}$ (step time of $2 \mathrm{~s}$ ).

Specific surface area, pore size distribution and pore volume measurements were obtained from $\mathrm{N}_{2}$ adsorption-desorption experiments. A known mass of sample was first outgassed under vacuum at $250^{\circ} \mathrm{C}$. Isotherms were obtained on a MICROMERITICS TRISTAR instrument. The specific surface area, $\mathrm{S}_{\mathrm{BET}}$, was calculated from the linear part of the BET plot. The mesopore size distribution was determined from the desorption branch using the BJH model. Mesopore volume was determined on the isotherms at $\mathrm{P} / \mathrm{P}_{0}=0.97$.

Noble metal particle distribution within the alumina grains was evaluated by Transmission Electronic Microscopy (TEM). Micrographs were collected on a JEOL 2100 instrument (operated at $200 \mathrm{kV}$ with a $\mathrm{LaB}_{6}$ source and equipped with a Gatan UltraScan camera).

\section{Results and Discussion}

The $\mathrm{C}_{10}$ mimCl structure (Figure 1) was confirmed by ${ }^{1} \mathrm{H}$ and ${ }^{13} \mathrm{C}$ NMR spectra (Figure 2).

The physical properties of the functionalized aluminas are gathered in Table $\mathbf{1 .}$

All the $N M$-aluminas synthesized exhibit isotherms of

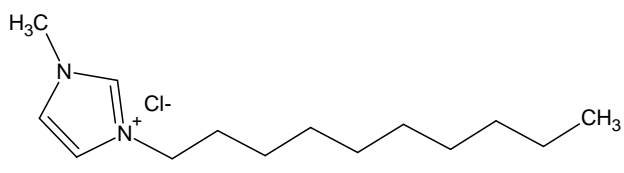

Figure 1. $\mathrm{C}_{10} \mathrm{mimCl}$ structure.

${ }^{1} \mathbf{H}$ NMR $\delta: 0.84(\mathrm{t}, \mathrm{J}=8 \mathrm{~Hz}, 3 \mathrm{H}), 1.20-1.40(\mathrm{~m}, 14 \mathrm{H}), 1.89(\mathrm{~m}, 2 \mathrm{H})$, $3.96(\mathrm{~s}, 3 \mathrm{H}), 4.27(\mathrm{t}, \mathrm{J}=8 \mathrm{~Hz}, 2 \mathrm{H}), 7.55(\mathrm{~s}, 1 \mathrm{H}), 7.58(\mathrm{~s}, 1 \mathrm{H})$.

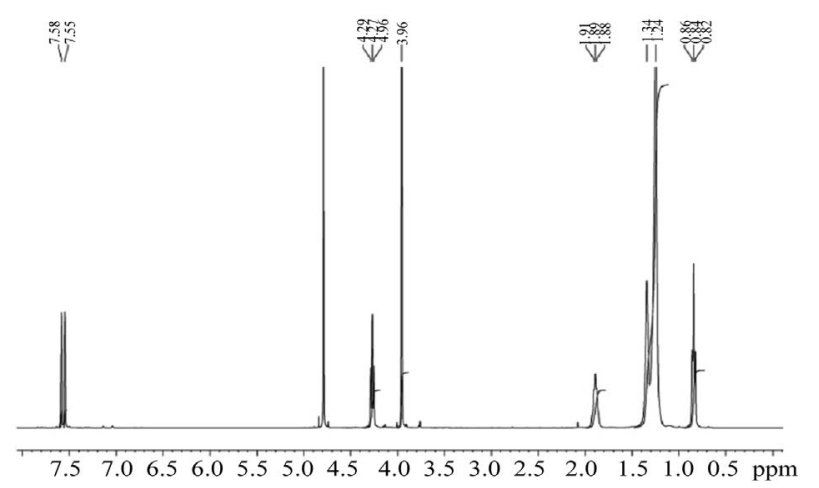

${ }^{13}$ C NMR $\delta: 13.78,22.56,26.09,29.07,29.38,29.51,29.70,29.74$, $29.84,31.88,35.87,49.47,122.06,123.79$

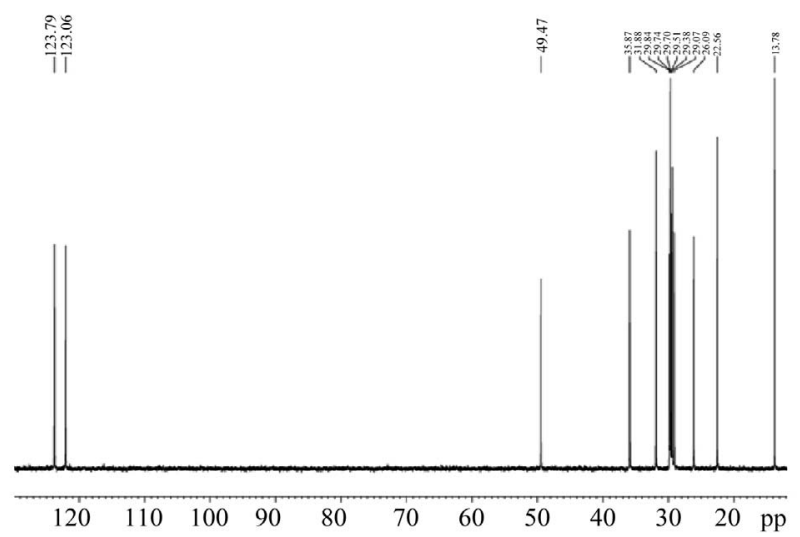

Figure 2. ${ }^{1} \mathrm{H}$ NMR and ${ }^{13} \mathrm{C}$ NMR of 1-decyl-3-methy limidazolium chloride. 
type IV with a type 2 hysteresis, according to the IUPAC classification [35], see Figure 3.

The Specific Surface Area $\left(\mathrm{S}_{\mathrm{BET}}\right)$ of the functionalized supports are relatively low (297 to $328 \mathrm{~m}^{2} \cdot \mathrm{g}^{-1}$ ) compared to the $S_{\mathrm{BET}}$ of the alumina synthesized without any noble metal $\left(380 \mathrm{~m}^{2} \cdot \mathrm{g}^{-1}\right)$. However, the method proposed here allows simply obtaining alumina with high $\mathrm{S}_{\mathrm{BET}}$, since $300 \mathrm{~m}^{2} \cdot \mathrm{g}^{-1}$ remains a high value. In addition, the protocol described here is simple to proceed, does not use organic solvent or toxic templating agent, and allows to obtain aluminas with competitive physical properties that is comparable or sometimes higher than that can be classically obtained. Indeed, classical routes generally lead to the production of surface areas below $300 \mathrm{~m}^{2} \cdot \mathrm{g}^{-1}$, when prepared by precipitation followed by thermal stabilization at similar temperature $[6,36]$. For obtaining mesostructured aluminas, precipitation route is often used since a uniform mesoporous distribution can be obtained by a precise control of the $\mathrm{pH}$ solution, the precipitation rate and the aging conditions [5,6,37-39]. Aluminas synthesized by this way often exhibit $\mathrm{S}_{\mathrm{BET}}$ comprised between 250 and $370 \mathrm{~m}^{2} \cdot \mathrm{g}^{-1}[37-40]$. However, a careful synthesis parameter control is needed to ensure a satisfying reproducibility of the synthesis. Another way of synthesis largely studied for mesostructured alumina is the sol-gel method. It has been studied since 1996 [7] and is still widely studied because the hydrolysis rate of the alumina precursor can be controlled, allowing a growth and agglomeration of crystallites adjustment $[3,7,41]$. By this

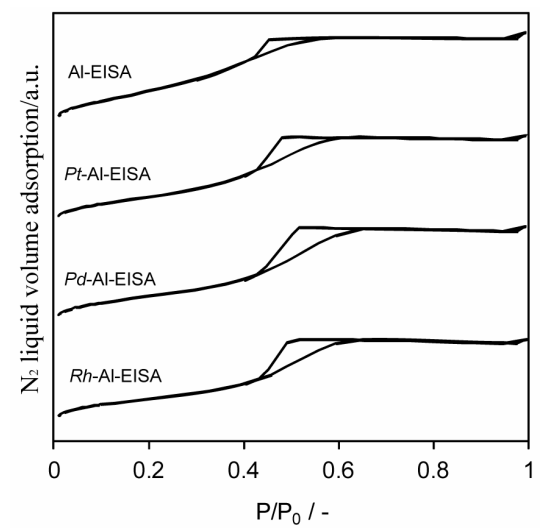

Figure 3. $\mathrm{N}_{2}$ adsorption-desorption isotherms obtained for the aluminas synthesized by EISA route.

Table 1. Physical properties of functionalized aluminas.

\begin{tabular}{cccccc}
\hline Sample & $\begin{array}{c}\mathrm{S}_{\mathrm{BET}} \\
\left(\mathrm{m}^{2} \cdot \mathrm{g}^{-1}\right)\end{array}$ & $\begin{array}{c}\mathrm{V}_{\mathrm{p}} \\
\left(\mathrm{cm}^{3} \cdot \mathrm{g}^{-1}\right)\end{array}$ & $\begin{array}{c}\mathrm{D}_{\mathrm{p}} \\
(\mathrm{nm})\end{array}$ & $\begin{array}{c}\text { Crystal } \\
\text { structure }\end{array}$ & $\begin{array}{c}\mathrm{d}_{\text {metal }} \\
(\mathrm{nm})\end{array}$ \\
\hline Al-EISA & 380 & 0.32 & 3.2 & $\mathrm{Al}_{2} \mathrm{O}_{3} \gamma$ & - \\
Pt-Al-EISA & 328 & 0.32 & 3.8 & $\mathrm{Pt}^{0}, \mathrm{Al}_{2} \mathrm{O}_{3} \gamma$ & 1.8 \\
Pd-Al-EISA & 323 & 0.33 & 3.9 & $\mathrm{Pd}^{0}, \mathrm{Al}_{2} \mathrm{O}_{3} \gamma$ & 4.9 \\
Rh-Al-EISA & 297 & 0.30 & 3.9 & $\mathrm{Al}_{2} \mathrm{O}_{3} \gamma$ & $\mathrm{nd}$ \\
\hline
\end{tabular}

method, aluminas with higher $\mathrm{S}_{\mathrm{BET}}$ can be obtained, $\sim 400$ $\mathrm{m}^{2} \cdot \mathrm{g}^{-1}$ [38]. However, the reproducibility and scaling up of these processes remain difficult, due to: 1) the necessity to carefully control the precursor concentration, generally low; 2) the use of inorganic solvents; 3 ) the increase in pressure during thermal crystallization.

The synthesis of ordered aluminas via classical Evaporation Induced Self Assembly has been first proposed by Niesz et al. [3] in 2005. The method of preparation the authors used is simple and reproducible, as evidenced thereafter by the numerous studies dealing with the synthesis of ordered aluminas during the past few years. In addition, highly ordered mesoporous aluminas with high surface areas, that means compatible with a use as catalysis support or adsorbent, can be obtained [4,42]. Yuan et al. [4] reported aluminas with $\mathrm{S}_{\mathrm{BET}}$ as high as $434 \mathrm{~m}^{2} \cdot \mathrm{g}^{-1}$, after thermal stabilization at $400^{\circ} \mathrm{C}$. By comparing the physical properties of $N M$-aluminas to the alumina alone, it appears that the mean pore diameter slightly increases when incorporating noble metals and the pore volume is still the same than without noble metal. Generally, the samples synthesized by EISA process exhibit large pore size when prepared using voluminous triblock copolymers as templates. Pore sizes obtained in this work, c.a. $3.2-3.9 \mathrm{~nm}$, are smaller than those classically reported for EISA synthesis, generally ranging from 5 to $7 \mathrm{~nm}$. This can be explained, first of all by the chain length of the ionic liquid used: ten carbons which will confer a limited size at the organized phase. Indeed, the RTILs are known to form micelles in aqueous solutions $[43,44]$. The diameter of the micelles as formed, depends on the alkyl chain length: around 1.3 $\mathrm{nm}$ to $2.7 \mathrm{~nm}$ for alkyl chains containing respectively from 4 to 10 carbon atoms $[45,46]$. In contrast, Pluronic P123 forms a micelle with an approximate diameter of 18 $\mathrm{nm}[46,47]$. In addition, the double role of the ionic liquid, solvent and porogen, makes the prediction of the pore size very difficult.

The wide angles XRD patterns of the alumina and noble metal functionalized materials show the characteristics of a $\gamma-\mathrm{Al}_{2} \mathrm{O}_{3}$. The crystallization of the alumina phase is preferable, since it confers to the solid a better thermal stability than in an amorphous material [36], as well as well-known surface properties [48]. Compared to the alumina synthesis by EISA where crystallization of the $\gamma$ phase is generally observed to occur at higher temperature, i.e. amorphous until $700^{\circ} \mathrm{C}$ in the Wan's work, crystallized at $800^{\circ} \mathrm{C}$ in the Yuan's work.

While no supplementary diffraction peak is observed for the $\mathrm{Rh}$ functionalized alumina, the diffraction patterns of the Pt-Al-EISA and Pd-Al-EISA show weak reflections attributed to the $\mathrm{Pt}^{0}$ and $\mathrm{Pd}^{0}$ phase respecttively (annoted by * and $\square$ respectively in Figure 4).

These results, the formation of an external phase and 


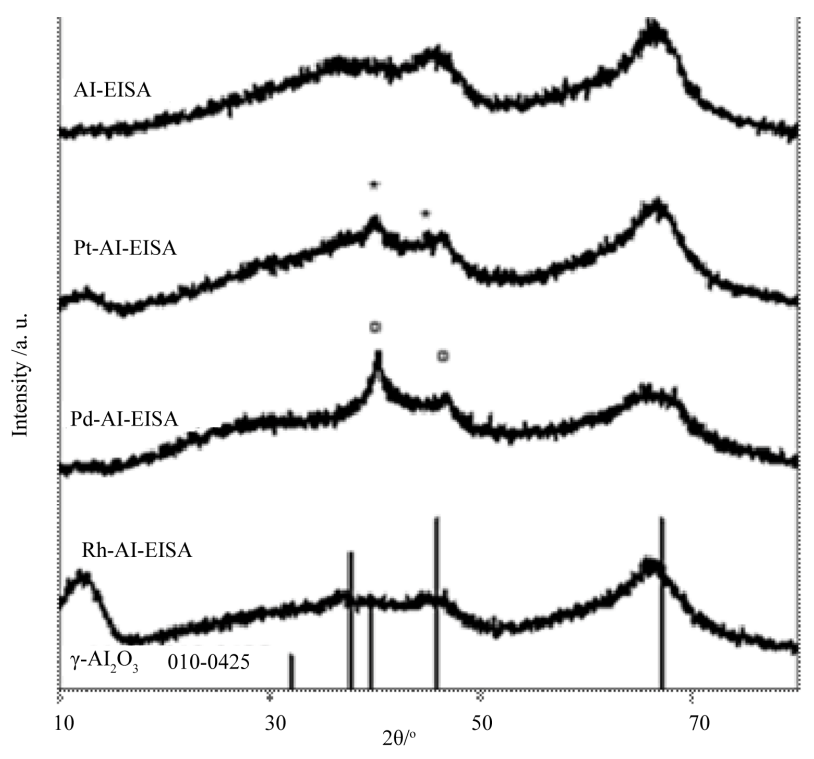

Figure 4. Wide angles XRD patterns of the aluminas.

its possible reduction, confirm that at least a part of the metal (case of $\mathrm{Pd}$ and $\mathrm{Pt}$ ) is not incorporating into the alumina framework, and is accessible for gas phase (possibility to reduce them). The particles sizes evaluated by $\mathrm{XRD}$, using the Debye-Scherrer equation after Warren's correction for instrumental broadening, are $1.8 \mathrm{~nm}$ and $4.9 \mathrm{~nm}$ for Pt-Al-EISA and Pd-Al-EISA respectively. Supported noble metal nanoparticles are then obtained in the case of the Pd and Pt based composites. The small Pt particle size evaluated by this method strongly suggests that the particles are dispersed inside the porosity with no difficulty of access due to the larger pore size of the support. For Pd-Al-EISA, the mean Pd particle size is evaluated at a size very close to that of the pore size support. Some support pore plugging by the metal nanoparticles can then occur in this solid, even if the metal loading remains low.

TEM analysis was performed on the materials to confirm the presence of metallic nanoparticles and their size in the alumina support. Representative TEM pictures are presented Figure 5. Some differences are easily observable:

For Pt-Al-EISA (Figure 5(A)), a homogeneous size and dispersion of the metallic particles in the alumina aggregates is observed. In addition, the mean size of 2 $\mathrm{nm}$ (Figure 6(A)) is close to the size evaluated from $\mathrm{X}$-ray line broadening.

For Rh-Al-EISA (Figure 5(B)) metallic nanoparticles are observed at high magnification even if no reflection was detected by XRD. The particles are however very small, with most of them presenting sizes below $2 \mathrm{~nm}$ (Figure 6(B)), that can explain the lack of reflection in XRD pattern.
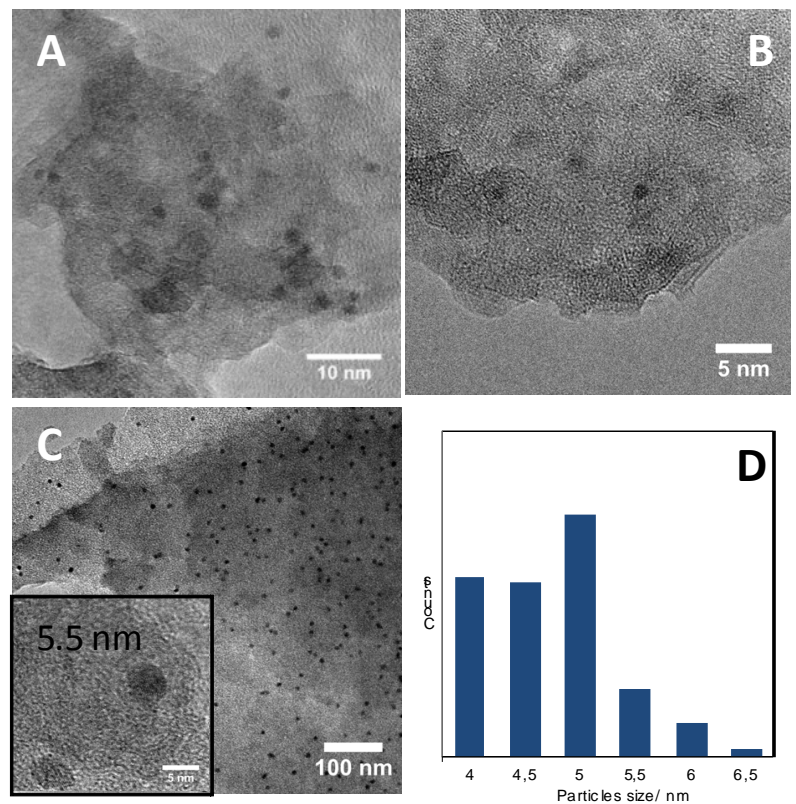

Figure 5. TEM images of $N M-\gamma-\mathrm{Al}_{2} \mathrm{O}_{3}$ (A) Pt, (B) Rh, (C) Pd and (D) Size distribution histogram of Pd).

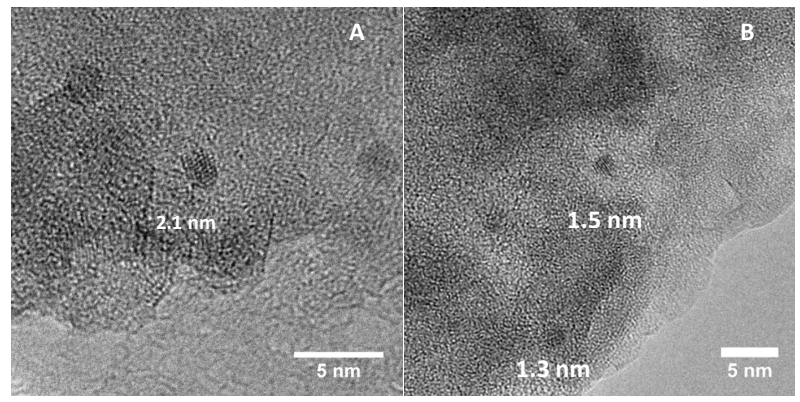

Figure 6. TEM images of Pt (A) and Rh (B) clusters in $\mathrm{Al}_{2} \mathrm{O}_{3}$ matrix.

For Pd-Al-EISA (Figure 5(C)), 4 - $6 \mathrm{~nm}$ palladium nanoparticles with homogeneous size and dispersion are visible located in the alumina aggregates. Focusing on the metallic particles allows the size measurement, which is observed to be mainly ranging from 4 to $5 \mathrm{~nm}$ (histogram of size distribution is given Figure 5(D)). This result is then in accordance with that obtained by XRD.

By a classical post grafting it is not easy to observe metallic particles with homogeneous size and dispersion [48-50].

For example, Osaki et al. [52] present a comparison between a one-pot sol-gel synthesis of $\mathrm{Pt}_{-} \mathrm{Al}_{2} \mathrm{O}_{3}$ and $\mathrm{Pt}$ post grafting. They show that by post grafting method, the metallic particle size is 2.5 times higher that by the one-pot synthesis and the homogeneity of the noble metal is very low $(<5 \%)$. At comparable calcination temperatures, it appears that $N M-\mathrm{Al}_{2} \mathrm{O}_{3}$ exhibit $\mathrm{S}_{\mathrm{BET}}<$ $200 \mathrm{~m}^{2} \cdot \mathrm{g}^{-1}$ with $N M$ particles sizes higher than $6 \mathrm{~nm}$.

Wang et al. [53] compare the physical properties of 
$\mathrm{Pd}-\mathrm{Al}_{2} \mathrm{O}_{3}$ synthesized by a one-pot sol gel method or post grafting method. The catalyst synthesized by post grafting method exhibits higher physical properties than the one obtained by the one pot synthesis. In their study the catalyst obtained in the latter case exhibits lower $\mathrm{S}_{\mathrm{BET}}$ and comparable pore diameter to our materials and contrary to our study, they demonstrate the necessity to use a stabilizer in the one pot synthesis in order to increase the physical properties of their catalyst.

By the one-pot synthesis described here, the incorporation of a metallic phase is possible at the first step of the synthesis, allowing the elimination of a preparation step (impregnation, grafting step). The as-obtained active phase is under the shape of dispersed nanoparticles in the alumina support. Even if palladium nanoparticles size is a little bit higher than for the other metals, an interesting homogeneity in size and dispersion is observed. These properties make these solids excellent model materials in the palladium chemistry field, including Suzuki cross coupling or Heck reactions [54-57]. In addition, all these materials present interesting physical properties like high surface area and pore size enough large for a use in gas phase reaction. These materials can also be considered for different applications such as hydrocarbons reforming, oxidation, hydrogenation or dehydrogenation reactions, $\mathrm{NO}_{\mathrm{x}}$ reduction [58-65].

To summarize, alumina supported noble metal nanoparticles are obtained using a simple way of synthesis. The ionothermal synthesis can advantageously replace the solvothermal process and facilitates the one-pot functionalization of the alumina support. The catalysts synthesized turned out interesting characteristics, like metallic nanoparticles well dispersed and homogeneous in size. In addition, whatever the noble metal used, the composites maintain competitive physical properties.

\section{Acknowledgements}

M. Bonne thanks the Région Poitou-Charentes for her Ph. D grant.

\section{REFERENCES}

[1] S. Che, Y. Sakamoto, O. Terasaki and T. Tatsumi, "The Structure and Morphology Control of Mesoporous Silica under Acidic Conditions," Microporous and Mesoporous Materials, Vol. 85, No. 3, 2005, pp. 207-218. doi:10.1016/j.micromeso.2005.04.029

[2] A. Galarneau, H. Cambon, F. Di Renzo, R. Ryoo, M. Choi and F. Fajula, "Microporosity and Connections between Pores in SBA-15 Mesostructured Silicas as a Function of the Temperature of Synthesis," New Journal of Chemistry, Vol. 27, No. 1, 2003, pp. 73-79. doi:10.1039/b207378c

[3] K. Niesz, P. Yang and G. A. Somerjai, "Sol-Gel Synthesis of Ordered Mesoporous Alumina," Chemical Communi- cations, No. 15, 2005, pp. 1986-1987. doi:10.1039/b419249d

[4] Q. Yuan, A.-X. Yin, C. Luo, L.-D. Sun, Y.-W. Zhang, W.-T. Duan, H.-C. Liu and C.-H. Yan, "Facile Synthesis for Ordered Mesoporous $\gamma$-Aluminas with High Thermal Stability," Journal of the American Chemical Society, Vol. 130, No. 11, 2008, pp. 3465-3472. doi: $10.1021 / \mathrm{ja} 0764308$

[5] K. Okada, T. Nagashima, Y. Kameshima, A. Yasumori and T. Tsukada, "Relationship between Formation Conditions, Properties, and Crystallite Size of Boehmite," Journal of Colloids and Interface Science, Vol. 253, No. 2, 2002, pp. 308-314. doi:10.1006/jcis.2002.8535

[6] R. Zhao, F. Guo, Y. Hu and H. Zhao, "Self-Assembly Synthesis of Organized Mesoporous Alumina by Precipitation Method in Aqueous Solution," Microporous and Mesoporous Materials, Vol. 93, No. 1-3, 2006, pp. 212216. doi:10.1016/j.micromeso.2006.02.024

[7] S. A. Bagshaw and T. J. Pinnavaia, "Mesoporous Alumina Molecular Sieves," Angewandte Chemie, International Edition, Vol. 35, No. 10, 1996, pp. 1102-1105. doi:10.1002/anie.199611021

[8] W. El-Nadjar, M. Bonne, E. Trela, L. Rouleau, A. Mino, S. Hocine, E. Payen, C. Lancelot, C. Lamonier, P. Blanchard, X. Courtois, F. Can, D. Duprez and S. Royer, "Infrared Investigation on Surface Properties of Alumina Obtained Using Recent Templating Routes," Microporous and Mesoporous Materials, Vol. 158, 2012, pp. 88-98. doi:10.1016/j.micromeso.2012.03.006

[9] Q. Zhang, K. De Oliveira Vigier, S. Royer and F. Jérôme, "Deep Eutectic Solvents: Syntheses, Properties and Applications," Chemical Society Reviews, Vol. 41, No. 21, 2012, pp. 7108-7146. doi:10.1039/c2cs35178a

[10] M. G. Del Pópolo and G. A. Voth, "On the Structure and Dynamics of Ionic Liquids," The Journal of Physical Chemistry B, Vol. 108, No. 5, 2004, pp. 1744-1752. doi:10.1021/jp0364699

[11] P. Wasserscheid and W. Keim, "Ionic Liquids-New 'Solutions' for Transition Metal Catalysis," Angewandte Chemie International Edition, Vol. 39, No. 21, 2000, pp. 3772-3789.

doi:10.1002/1521-3773(20001103)39:21<3772::AID-AN IE3772>3.0.CO;2-5

[12] W.-S. Dong, M.-Y. Li, C. Liu, F. Lin and Z. Liu, "Novel Ionic Liquid Assisted Synthesis of $\mathrm{SnO}_{2}$ Microspheres," Journal of Colloids and Interface Science, Vol. 319, No. 1, 2008, pp. 115-122. doi:10.1016/j.jcis.2007.08.031

[13] J. L. Anthony, E. J. Maginn and J. F. Brennecke, "Solution Thermodynamics of Imidazolium-Based Ionic Liquids and Water," The Journal of Physical Chemistry B, Vol. 105, 2001, pp. 10942-10949. doi:10.1021/jp0112368

[14] V. Rumbau, R. Marcilla, E. Ochoteco, J. A. Pomposo and D. Mercerreyes, "Ionic Liquid Immobilized Enzyme for Biocatalytic Synthesis of Conducting Polyaniline," Macromolecules, Vol. 39, No. 25, 2006, pp. 8547-8549. doi:10.1021/ma061196b

[15] A. Safavi, N. Maleki and M. Bagheri, "Modification of Chemical Performance of Dopants in Xerogel Films with Entrapped Ionic Liquid," Journal of Materials Chemistry, 
Vol. 17, No. 17, 2007, pp. 1674-1681. doi: $10.1039 / \mathrm{b} 613288 \mathrm{j}$

[16] C. Zhang, J. Chen, Y. Zhou and D. Li, "Ionic LiquidBased 'All-in-One' Synthesis and Photoluminescence Pro-perties of Lanthanide Fluorides," The Journal of Physical Chemistry C, Vol. 112, No. 27, 2008, pp. 10083-10088. doi:10.1021/jp802083q

[17] Y. Qin, Y. Song, N. Sun, N. Zhao, M. Li and L. Qi, "Ionic Liquid-Assisted Growth of Single-Crystalline Dendritic Gold Nanostructures with a Three-Fold Symmetry," Chemistry of Materials, Vol. 20, No. 12, 2008, pp. 3965- 3972. doi: $10.1021 / \mathrm{cm} 8002386$

[18] T. L. Greaves and C. J. Drummond, "Ionic liquids as Amphiphile Self-Assembly Media," Chemical Society Reviews, Vol. 37, No. 8, 2008, pp. 1709-1726. doi:10.1039/b801395k

[19] M. Behboudnia, A. Habibi-Yangjeh, Y. Jafari-Tarzanag and A. Khodayari, "Preparation and Characterization of Monodispersed Nanocrystalline $\mathrm{ZnS}$ in Water-Rich [EMIM] $\mathrm{EtSO}_{4}$ Ionic Liquid Using Ultrasonic Irradiation," Journal of Crystal Growth, Vol. 310, No. 21, 2008, pp. 45444548. doi:10.1016/j.jcrysgro.2008.07.104

[20] A. Taubert, A. Uhlmann, A. Hedderich and K. Kirchhoff, "CuO Particles from Ionic Liquid/Water Mixtures: Evidence for Growth via $\mathrm{Cu}(\mathrm{OH})_{2}$ Nanorod Assembly and Fusion," Inorganic Chemistry, Vol. 47, No. 22, 2008, pp. 10758-10764. doi:10.1021/ic801335k

[21] Z. Li, A. Shkilnyy and A. Taubert, "Room Temperature $\mathrm{ZnO}$ Mesocrystal Formation in the Hydrated Ionic Liquid Precursor (ILP) Tetrabutylammonium Hydroxide," Crystal Growth and Design, Vol. 8, No. 12, 2008, pp. 45264532. doi:10.1021/cg8005426

[22] H. K. Farag, M. A. Zoubi and F. Endres, "Sol-Gel Synthesis of Alumina, Titania and Mixed Alumina/Titania in the Ionic Liquid 1-Butyl-1-Methylpyrrolidinium bis(trifluoromethylsulphonyl) Amide," Journal of Material Science, Vol. 44, No. 1, 2009, pp. 122-128. doi:10.1007/s10853-008-3107-y

[23] Z. Li, Z. Jia, Y. Luan and T. Mu, "Ionic Liquids for Synthesis of Inorganic Nanomaterials," Current Opinion in Solid State and Materials Science, Vol. 12, No. 1, 2009, pp. 1-8. doi:10.1016/j.cossms.2009.01.002

[24] Y. Hou, A. Kong, X. Zhao, H. Zhu and Y. Shan, "Synthesis of High Surface Area Mesoporous Carbonates in Novel Ionic Liquid," Material Letters, Vol. 63, No. 12, 2009, pp. 1061-1064. doi:10.1016/j.matlet.2009.02.005

[25] J. Zhuang, Y. Ma, F. Shi, L. Liu and Y. Deng, "Room Temperature Ionic Liquids as Templates in the Synthesis of Mesoporous Silica via a Sol-Gel Method," Microporous and Mesoporous Materials, Vol. 119, No. 1-3,2009, pp. 97-103. doi:10.1016/j.micromeso.2008.10.003

[26] J. Lian, J. Ma, X. Duan, T. Kim, H. Li and W. Zheng, "One-Step Ionothermal Synthesis of $\gamma-\mathrm{Al}_{2} \mathrm{O}_{3}$ Mesoporous Nanoflakes at Low Temperature," Chemical Communications, Vol. 46, No. 15, 2010, pp. 2650-2652. doi:10.1039/b921787h

[27] L.-L. Li, W.-M. Zhang, Q. Yuan, Z.-X. Li, C.-J. Fang, L.-D. Sun, L.-J. Wan and C.-H. Yan, "Room Temperature Ionic Liquids Assisted Green Synthesis of Nano-crystal- line Porous $\mathrm{SnO}_{2}$ and Their Gas Sensor Behaviors," Crystal Growth and Design, Vol. 8, No. 11, 2008, pp. 4165-4172. doi:10.1021/cg800686w

[28] A. Jia, J. Li, Y. Zhang, Y. Song and S. Liu, "Synthesis and Characterization of Nanosized Micro-Mesoporous $\mathrm{Zr}-\mathrm{SiO}_{2}$ via Ionic Liquid Templating," Materials Science and Engineering C, Vol. 28, No. 8, 2008, pp. 1217-1226. doi:10.1016/j.msec.2007.11.002

[29] N. Žilková, A. Zukal and J. Čejka, "Synthesis of Organized Mesoporous Alumina Templated with Ionic Liquids," Microporous and Mesoporous Materials, Vol. 95, No. 1-3, 2006, pp. 176-179. doi:10.1016/j.micromeso.2006.05.016

[30] H. Park, S. H. Yang, Y. S. Jun, W. H. Hong and J. K. Kang, "Facile Route to Synthesize Large-Mesoporous $\gamma$ Alumina by Room Temperature Ionic Liquids," Chemistry of Materials, Vol. 19, No. 3, 2007, pp. 535-542. doi: $10.1021 / \mathrm{cm} 0620887$

[31] L.A. Aslanov, M.A. Zakharov, E.E. Knyazeva and A. V. Yatsenko, "Preparation of Mesoporous Aluminum Hydroxide and Oxide in Ionic Liquids," Russian Journal of Inorganic Chemistry, Vol. 52, No. 10, 2007, pp. 15111513. doi:10.1134/S0036023607100051

[32] D. Y. Li, Y. S.Lin, Y. C. Li, D. L. Shieh and J. L. Lin, "Synthesis of Mesoporous Pseudoboehmite and Alumina Templated with 1-Hexadecyl-2,3-Dimethyl-Imidazolium Chloride," Microporous and Mesoporous Materials, Vol. 108,No. 1-3, 2008, pp. 276-282. doi:10.1016/j.micromeso.2007.04.009

[33] H. K. Farag and F. Endres, "Studies on the Synthesis of Nano-Alumina in Air and Water Stable Ionic Liquids," Journal of Material Chemistry, Vol. 18, No. 4, 2008, pp. 442-449. doi:10.1039/b711704c

[34] A. Mele, C. D. Tran and S. H. De Paoli Lacerda, "The Structure of a Room-Temperature Ionic Liquid with and without Trace Amounts of Water: The Role of C-H $\cdots \mathrm{O}$ and $\mathrm{C}-\mathrm{H} \cdots \mathrm{O}$ Interactions in 1- $n$-Butyl-3-Methyli-midazolium Tetrafluoroborate," Angewandte Chemie International Edition, Vol. 42, No. 36, 2003, pp. 4364-4366. doi:10.1002/anie. 200351783

[35] K. S. W. Sing, D. H. Everett, R. H. W. Haul, L. Moscou, R. A. Pieroti, J. Rouquerol and T. Siemieniewska, "Reporting Physisorption Data for Gas/Solid Systems with Special Reference to the Determination of Surface Area and Porosity," Pure and Applied Chemistry, Vol. 57, No. 4, 1985, pp. 603-619. doi:10.1351/pac198557040603

[36] A.-P. Su, Y. Zhou, Y.-H. Yao, C.-M. Yang and H. Du, “A Facile Rout to Synthesis Lamellate Structure Mesoporous Alumina Using Polyethylene Glycol 6000 (PEG, Molecular Weight $=6000$ ) as Structure Directing Agent," Microporous and Mesoporous Materials, Vol. 159, 2012, pp. 36-41. doi:10.1016/j.micromeso.2012.04.002

[37] Z. Zhang and T. J. Pinnavaia, "Mesostructured $\gamma-\mathrm{Al}_{2} \mathrm{O}_{3}$ with a Lathlike Framework Morphology," Journal of the American Chemical Society, Vol. 124, No. 41, 2002, pp. 12294-12301. doi:10.1021/ja0208299

[38] P. Bai, W. Xing, Z. Zhang and Z. Yan, "Facile Synthesis of Thermally Stable Mesoporous Crystalline Alumina by Using a Novel Cation-Anion Double Hydrolysis Method," 
Material Letters, Vol. 59, No. 25, 2005, pp. 3128-3131. doi:10.1016/j.matlet.2005.05.033

[39] P. Bai, P. Wu, G. Zhao, Z. Yan and X. S. Zhao, "CationAnion Double Hydrolysis Derived $\gamma-\mathrm{Al}_{2} \mathrm{O}_{3}$ as an Environmentally Friendly and Efficient Aldol Reaction Catalyst," Journal of Materials Chemistry, Vol. 18, No. 1, 2008, pp. 74-76. doi:10.1039/b713283b

[40] S. Royer, C. Leroux, R. Revel, L. Rouleau and S. Morin, "Synthesis and Surface Reactivity of Nanocomposite Support $\mathrm{Al}_{2} \mathrm{O}_{3} / \alpha-\mathrm{Al}_{2} \mathrm{O}_{3}$," Studies in Surface Science and Catalysis, Vol. 162, 2006, pp. 441-448. doi:10.1016/S0167-2991(06)80938-9

[41] R. W. Hicks and T. J. Pinnavaia, "Nanoparticle Assembly of Mesoporous AlOOH (Boehmite)," Chemistry of Materials, Vol. 15, No. 1, 2003, pp. 78-82. doi: $10.1021 / \mathrm{cm} 020753 \mathrm{f}$

[42] L. Wan, H. Fu, K. Shi and X. Tian, "Facile Synthesis of Ordered Nanocrystalline Alumina Thin Films with Tunable Mesopore Structures," Microporous and Mesoporous Materials, Vol. 115, No. 3, 2008, pp. 301-307. doi:10.1016/j.micromeso.2008.02.004

[43] P. Mukherjee, J. A. Crank, M. Halder, D. W. Armstrong and J. W. Petrich, "Assessing the Roles of the Constituents of Ionic Liquids in Dynamic Solvation: Comparison of an Ionic Liquid in Micellar and Bulk Form," The Journal of Physical Chemistry A, Vol. 110, No. 37, 2006, pp. 10725-10730. doi:10.1021/jp063433i

[44] P. Mukherjee, J. A. Crank, P. S. Sharma, A. B. Wijeratne, R. Adhikary, S. Bose, D. W. Armstrong and J. W. Petrich, "Dynamic Solvation in Phosphonium Ionic Liquids: Comparison of Bulk and Micellar Systems and Considerations for the Construction of the Solvation Correlation Function, $C(t)$," The Journal of Physical Chemistry B, Vol. 112, No. 11, 2008, pp. 3390-3396. doi:10.1021/jp7107126

[45] A. Triolo, O. Russina, H.-J. Bleif and E. Di Cola, "Nanoscale Segregation in Room Temperature Ionic Liquids," The Journal of Physical Chemistry B, Vol. 111, No. 8, 2007, pp. 4641-4644. doi:10.1021/jp067705t

[46] S. Dey, A. Adhikari, D. K. Das, D. K. Sasmal and K. Bhattacharyya, "Femtosecond Solvation Dynamics in a Micron-Sized Aggregate of an Ionic Liquid and P123 Triblock Copolymer," The Journal Physical Chemistry B, Vol. 113, No. 4, 2009, pp. 959-965. doi:10.1021/jp804401p

[47] I. Goldmints, K. von Gottberg, K. A. Smith and T. A. Hatton, "Small-Angle Neutron Scattering Study of PEO-PPOPEO Micelle Structure in the Unimer-to-Micelle Transition Region," Langmuir, Vol. 13, No. 14, 1997, pp. 3659-3664. doi:10.1021/la970140v

[48] Y. Liu and T. Pinnavaia, "Aluminosilicate Mesostructures with Improved Acidity and Hydrothermal Stability," Journal of Materials Chemistry, Vol. 12, No. 11, 2002, pp. 3179-3190. doi:10.1039/b204094h

[49] S. Sugiyama, T. Bando, H. Tanaka, K. Nakagawa, K.-I. Sotowa, Y. Katou, T. Mori, T. Yasukawa and W. Ninomiya, "Direct Oxidative Esterification of Propionaldehyde to Methyl Propionate Using Heavy-Metal-Free Palladium Catalysts under Pressurized Oxygen," Journal of
Japanese Petroleum Institution, Vol. 54, No. 1, 2011, pp. 380-384. doi:10.1627/jpi.54.380

[50] Q. Lin, K.-I. Shimizu and A. Satsuma, "Kinetic Analysis of Reduction Process of Supported $\mathrm{Rh} / \mathrm{Al}_{2} \mathrm{O}_{3}$ Catalysts by Time Resolved in situ UV-vis Spectroscopy," Applied Catalysis A, Vol. 419-420, 2012, pp. 142-147. doi:10.1016/j.apcata.2012.01.021

[51] S. Scirè, S. Giuffrida, C. Crisafulli, P. M. Riccobene and A. Pistone, "Liquid Phase Photo-Deposition in the Presence of Unmodified $\beta$-Cyclodextrin: A New Approach for the Preparation of Supported Pd Catalysts," Journal of Molecular Catalysis A, Vol. 353-354, 2012, pp. 87-94. doi:10.1016/i.molcata.2011.11.009

[52] T. Osaki, S. Shima, T. Miki and Y. Tai, "Improved Thermal Stability of $\mathrm{Pt} / \mathrm{Al}_{2} \mathrm{O}_{3}$ Cryogels by Controlling Sol-Gel Conditions," Catalysis Letters, Vol. 142, No. 5, 2012, pp. 541-546. doi:10.1007/s10562-012-0811-7

[53] Y. Wang, X. Huang, X. Liao and B. Shi, "Preparation of Highly Active and Reusable Heterogeneous $\mathrm{Al}_{2} \mathrm{O}_{3}-\mathrm{Pd} \mathrm{Ca}-$ talysts by the Sol-Gel Method Using Bayberry Tannin as Stabilizer," Research on Chemical Intermediates, Vol. 38, No. 7, 2012, pp. 1609-1618. doi:10.1007/s11164-012-0487-z

[54] J. Terao and N. Kambe, "Cross-Coupling Reaction of Alkyl Halides with Grignard Reagents Catalyzed by $\mathrm{Ni}$, $\mathrm{Pd}$, or $\mathrm{Cu}$ Complexes with $\pi$-Carbon Ligand(s)," Accounts of Chemical Research, Vol. 41, No. 11, 2008, pp. 15451554. doi:10.1021/ar800138a

[55] L. Shao, W. Ji, P. Dong, M. Zeng, C. Qi and X.-M. Zhang, "Coupling Reactions of Aromatic Halides with Palladium Catalyst Immobilized on Poly(Vinyl Alcohol) Nanofiber Mats," Applied Catalysis A, Vol. 413-414, 2012, pp. 267-272. doi:10.1016/j.apcata.2011.11.018

[56] F. Zhang, J. Niu, H. Wang, H. Yang, J. Jin, N. Liu, Y. Zhang, R. Li and J. Ma, "Palladium Was Supported on Superparamagnetic Nanoparticles: A Magnetically Recoverable Catalyst for Heck Reaction," Materials Research Bulletin, Vol. 47, No. 2, 2012, pp. 504-507. doi:10.1016/j.materresbull.2011.10.030

[57] M. Pérez-Lorenzo, "Palladium Nanoparticles as Efficient Catalysts for Suzuki Cross-Coupling Reactions," The Journal of Physical Chemistry Letters, Vol. 3, No. 2, 2012, pp. 167-174. doi:10.1021/jz2013984

[58] S. Barama, C. Dupeyrat-Batiot, M. Capron, E. BordesRichard and O. Bakhti-Mohammedi, "Catalytic Properties of $\mathrm{Rh}, \mathrm{Ni}, \mathrm{Pd}$ and Ce Supported on Al-Pillared Montmorillonites in Dry Reforming of Methane," Catalysis Today, Vol. 141, No. 3-4, 2009, pp. 385-392. doi:10.1016/j.cattod.2008.06.025

[59] T. Hamoule, M. H. Peyrovi, M. Rashidzadeh and M. R. Toosi, "Catalytic Reforming of n-Heptane over Pt/AlHMS Catalysts," Catalysis Communications, Vol. 16, No. 1, 2011, pp. 234-239. doi:10.1016/j.catcom.2011.09.020

[60] J. Yu, Q. Ge, W. Fang and H. Xu, "Enhanced Performance of Ca-Doped $\mathrm{Pt} / \gamma-\mathrm{Al}_{2} \mathrm{O}_{3}$ Catalyst for Cyclohexane Dehydrogenation," International Journal of Hydrogen Energy, Vol. 36, No. 18, 2011, pp. 11536-11544. doi:10.1016/j.ijhydene.2011.06.066

[61] S. Handjani, E. Marceau, J. Blanchard, J.-M. Krafft, M. 
Che, P. Mäki-Arvela, N. Kumar, J. Wärna and D. Y. Murzin, "Influence of the Support Composition and Acidity on the Catalytic Properties of Mesoporous SBA-15, Al-SBA-15, and $\mathrm{Al}_{2} \mathrm{O}_{3}$-Supported $\mathrm{Pt}$ Catalysts for Cinnamaldehyde Hydrogenation," Journal of Catalysis, Vol. 282, No. 1, 2011, pp. 228-236. doi:10.1016/j.jcat.2011.06.017

[62] J. Duan, J. Han, H. Sun, P. Chen, H. Lou and X. Zheng, "Diesel-Like Hydrocarbons Obtained by Direct Hydrodeoxygenation of Sunflower Oil over Pd/Al-SBA-15 Catalysts," Catalysis Communications, Vol. 17, 2012, pp. 76-80. doi:10.1016/j.catcom.2011.10.009

[63] M. E. Domine, M. C. Hernández-Soto, M. T. Navarro and Y. Pérez, "Pt and Pd Nanoparticles Supported on Structured Materials as Catalysts for the Selective Reductive Amina- tion of Carbonyl Compounds," Catalysis Today, Vol. 172, No. 1, 2011, pp. 13-20.

doi:10.1016/j.cattod.2011.05.013

[64] A. Barrera, S. Fuentes, G. Díaz, A. Gómez-Cortés, F. Tzompantzi and J. C. Molina, "Methane Oxidation over Pd Catalysts Supported on Binary $\mathrm{Al}_{2} \mathrm{O}_{3}-\mathrm{La}_{2} \mathrm{O}_{3}$ Oxides Prepared by the Sol-Gel Method," Fuel, Vol. 93, 2012, pp. 136-141. doi:10.1016/j.fuel.2011.11.049

[65] A. Pietraszek, P. Da Costa, R. Marques, P. Kornelak, T. W. Hansen, J. Camra and M. Najbar, "The Effect of the Rh-Al, Pt-Al and Pt-Rh-Al Surface Alloys on NO Conversion to $\mathrm{N}_{2}$ on Alumina Supported $\mathrm{Rh}, \mathrm{Pt}$ and Pt-Rh Catalysts," Catalysis Today, Vol. 119, No. 1-4, 2007, pp. 187-193. doi:10.1016/j.cattod.2006.08.009 